\title{
ANALISIS TAKSOMETRI Anthurium SCHOTT (ARACEAE)
}

\author{
Muhammad Falah, Pudji Widodo, HeXa Apriliana Hidayah
}

Fakultas Biologi, Universitas Jenderal Soedirman, Jalan dr. Suparno 63 Purwokerto 53122

\section{A B S T R A C T}

Anthurium Schott is one of the commercial ornamental plants in Indonesia. This genus has a high morphological variation amongst its species. This study aims to determine the similarity relationship amongst Anthurium based on morphological characters including stems, leaves, and inflorescences. This study was carried out from June to July 2012 in several locations in Purwokerto and Baturraden area, and Balai Benih Tanaman Pangan dan Hortikultura (B2TPH) Banyumas Regency. This study used explorative method with purposive random sampling. The results of the analysis using the UPGMA (Unweighted Pair Group Method with Arithmetic Mean) showed that there were 17 taxa which can be classified into 4 groups. Group I consisted of A. andraeanum "Renoir Pink", A. andraeanum "Safari", A. andraeanum "White", A. andraeanum "Tropical", A. andraeanum "cv. 1", A. andraeanum "Amigo", and A. nymphaeifolium. Group II consisted of $A$. pedatoradiatum ssp. helleborifolium, A. crystallinum, A. andicola "Kuku Bima" and A. andicola "Red List". Group III consisted of $A$. crassinervium "Crispimarginatum" and A. plowmanii. Group IV consisted of A. hookeri "Garuda", A. hookeri "Red Hookeri", A. bonplandii ssp. guayanum, and A. jenmanii. Group I was the sister group of Group II, as well as Group III to Group IV. The closest similarity relationship was between A. andraeanum "Renoir Pink" and A. andraeanum "Safari", whereas the farthest one was between $A$. bonplandii ssp. guayanum and A. andraeanum "Tropical".

KEY WORDS: Anthurium, Araceae, cultivars, phenetic, taximetrics

Penulis korespondensi: MuHAMmAD FALAH | email: knimic.me@gmail.com

\section{PENDAHUL U A N}

Anthurium dikenal sebagai tanaman hias komersial di Indonesia. Tanaman ini disukai konsumen karena keindahan warna dan variasi bentuk bunga, serta variasi bentuk daun. Secara garis besar, Anthurium dapat digolongkan menjadi Anthurium berseludang bunga (spathae) indah dan berdaun indah (Budhiprawira dan Saraswati, 2006). Anthurium berseludang bunga indah mempunyai daun yang kurang menarik dan biasanya dijadikan sebagai bunga potong, sedangkan Anthurium berdaun indah mempunyai bunga yang kurang menarik dan dijadikan tanaman hias dalam pot (Bailey, 1963). Secara ekonomi, Anthurium pernah menjadi primadona pada sekitar tahun 2006-2007. Harga Anthurium berdaun indah terutama A. plowmanii Croat (Gelombang Cinta) dan A. hookeri Kunth dapat mencapai puluhan juta rupiah dari semula hanya berharga ratusan ribu rupiah. Demikian pula dengan harga biji dan anakannya yang ikut terdongkrak dikarenakan permintaan pasar yang tinggi, sehingga pada saat itu banyak pedagang dan petani tanaman hias yang meningkat pendapatannya (Suryanto, 2010). Namun, menurut Zagoto (2012), pada tahun 2010 Anthurium masih bertahan menjadi primadona dan mempunyai harga yang mahal terutama pada berbagai kultivar $A$. jenmanii Engl. Menurutnya, Anthurium yang turun harganya secara drastis adalah $A$. plowmanii. Hal ini disebabkan $A$. plowmanii lebih mudah untuk dibudidayakan dan ketidaktahuan masyarakat tentang kelebihan dan keindahan Anthurium.

Genus Anthurium termasuk tanaman dari familia Araceae. Tanaman ini masih berkerabat dengan sejumlah tanaman hias seperti Aglaonema, Philodendron, dan keladi hias (Anonymous, 2012). Nama Anthurium berasal dari bahasa Yunani yaitu anthos dan oura, artinya bunga ekor (Rukmana, 1997). Menurut Martasari et al. (2009), karakteristik umum pada tanaman Anthurium yaitu memiliki perawakan herba, batang tumbuh di atas tanah, memiliki bukubuku, filotaksis daun terserak, berdaun tunggal, secara umum warna tangkai daun hijau, terdapat sendi, warna permukaan helaian daun bagian bawah hijau pucat, dan pertulangan daun memata jala. Anthurium memiliki perbungaan aksilar yang tak terbatas, jenis bunga tongkol (spadix), susunan bunga spirositik, memiliki braktea berupa seludang bunga (spathae), dan tidak memiliki brakteola. Karakteristik bunga seperti dijelaskan oleh Mayo et al. (1997) dalam Chouteau et al. (2006), yaitu bunga berbentuk segi empat, bunga duduk, memiliki 4 buah tepal, 4 buah tangkai sari (stamen), dan satu buah putik (pistillum). Secara konvensional, perbanyakan Anthurium dapat dilakukan melalui biji dan pemisahan anakan. Namun, perbanyakan dengan menggunakan teknik ini memerlukan waktu yang cukup lama (Hamidah et al., 1997). Anthurium dapat diperbanyak menggunakan teknik stek, baik stek batang maupun stek pucuk, cangkok, dan kultur jaringan. Perbanyakan Anthurium menggunakan teknik ini memerlukan waktu yang relatif lebih cepat sehingga sering digunakan para pecinta dan penjual tanaman hias untuk memenuhi kebutuhan pasar (Lie dan Andoko, 2007).

Terry (2000) dalam Martasari et al. (2009), menyatakan bahwa dalam rangka menunjang keberhasilan penyilangan, mengetahui hubungan taksonomik di antara spesies perlu dilakukan. Menurut Clifford dan Stephenson (1975), hubungan taksonomik mencakup dua pengertian yaitu hubungan filogenetik dan hubungan fenetik. Hubungan filogenetik adalah hubungan antara takson yang satu dengan yang lain berdasarkan asal nenek moyangnya, sedangkan hubungan fenetik adalah hubungan yang 
didasarkan pada persamaan dan perbedaan ciri yang tampak pada suatu taksa. Hubungan fenetik akan menghasilkan klasifikasi fenetik yang merupakan similaritas (kemiripan) dari individu dengan pertimbangan berdasarkan karakter fenotip (Shukla dan Misra, 1982). Semakin besar jumlah fenotip yang mirip berarti semakin dekat hubungan fenetik antar individu yang dibandingkan, semakin kecil jumlah fenotip yang mirip berarti semakin jauh hubungan fenetiknya (Sneath dan Sokal, 1973).

Penentuan jauh dekatnya hubungan fenetik antar individu yang dibandingkan dapat dilakukan melalui Taksonomi Numerik. Taksonomi Numerik atau Taksometri adalah salah satu metode untuk menentukan jauh dekatnya hubungan kemiripan dan penggolongan suatu taksa dengan pendekatan numerik. Analisis Taksometri ditentukan melalui karakter dan sifat morfologi yang diberi bobot yang sama, karena semua karakter dianggap sama pentingnya, sehingga mengurangi subjektivitas peneliti terhadap suatu taksa (Rogers, 1963; Davis dan Heywood, 1975; Sneath dan Sokal, 1973).

Berdasarkan uraian tersebut di atas, dapat dirumuskan permasalahan yaitu bagaimana hubungan kemiripan antar Anthurium berdasarkan karakter morfologinya. Berdasarkan permasalahan tersebut, telah dilakukan penelitian tentang variasi ciri morfologi berbagai Anthurium baik pada bagian vegetatif maupun generatifnya untuk mengetahui hubungan kemiripan antar Anthurium. Masing-masing tanaman Anthurium kemudian diidentifikasi dan dianalisis hubungan kemiripannya. Tujuan penelitian ini adalah untuk mengetahui hubungan kemiripan antar Anthurium berdasarkan karakter morfologi. Manfaat penelitian ini diharapkan dapat memberikan informasi ilmiah tentang hubungan kemiripan antar Anthurium yang dapat dimanfaatkan sebagai sumber informasi bagi tujuan pemuliaan tanaman Anthurium.

\section{MET O D E}

Bahan yang digunakan dalam penelitian ini adalah tanaman Anthurium yang didapat dari berbagai lokasi di eks-Kotatip Purwokerto dan Baturraden, serta Balai Benih Tanaman Pangan dan Hortikultura (B2TPH) Kabupaten Banyumas. Penelitian ini dilaksanakan selama dua bulan, yaitu bulan Juni-Juli 2012. Identifikasi tanaman Anthurium, pengamatan, dan pengukuran karakter morfologinya dilakukan secara langsung di lapangan.

Metode yang digunakan dalam penelitian ini adalah metode eksploratif. Teknik pengambilan sampel dilakukan secara acak terpilih (Purposive Random Sampling). Adapun cara kerja penelitian adalah sebagai berikut:

1. Dilakukan pengambilan sampel tanaman Anthurium yang terdapat di berbagai lokasi di eks- Kotatip Purwokerto dan Baturraden, serta Balai Benih Tanaman Pangan dan Hortikultura (B2TPH) Kabupaten Banyumas.

2. Tanaman Anthurium yang ditemukan diidentifikasi berdasarkan pustaka dari Croat dan Sheffer (1983), Croat (1991), Brown (2000), Kadir (2007), Ratnasari dan Krisantini (2007), dan Carlsen (2011).

3. Dilakukan pengamatan dan pengukuran bagian- bagian morfologi tanaman Anthurium secara langsung di lapangan.
4. Karakter morfologi yang diamati sebanyak 42 karakter, ditunjukan pada tabel 1 sebagai berikut:

Tabel 1. Karakter morfologi Anthurium Schott yang diamati

\begin{tabular}{lll}
\hline & \multicolumn{1}{c}{ Batang } \\
\hline 1 & Tinggi tanaman & \\
2 & Diameter batang & \\
3 & Keberadaan daun sisik (cataphyll) \\
4 & Tekstur daun sisik & \\
\hline & & Daun \\
\hline
\end{tabular}

5 Panjang helaian daun

6 Lebar helaian daun

7 Keberadaan torehan pada pangkal daun

8 Posisi torehan pada pangkal daun

9 Bentuk helaian daun pada pangkal daun yang tidak bertoreh

10 Bentuk helaian daun pada pangkal daun yang bertoreh

11 Bentuk ujung helaian daun

12 Bentuk pangkal helaian daun

13 Bentuk tepi helaian daun

14 Tekstur permukaan helaian daun bagian atas

15 Intensitas warna hijau pada permukaan helaian daun bagian atas

16 Intensitas warna hijau pada permukaan helaian daun bagian bawah

17 Intensitas kilap pada permukaan helaian daun bagian atas

18 Pertulangan daun

19 Warna pertulangan tulang daun

20 Kenampakan pertulangan daun terhadap permukaan helaian daun bagian atas

21 Panjang tangkai daun

22 Diameter tangkai daun

23 Bentuk penampang melintang tangkai daun

24 Keberadaan alur pada tangkai daun

25 Warna tangkai daun

Bunga Majemuk

26 Panjang tangkai bunga

27 Diameter tangkai bunga

28 Warna tangkai bunga

29 Letak seludang bunga (spatha) terhadap helaian daun

30 Panjang seludang bunga

31 Ukuran seludang bunga pada bagian terlebar

32 Bentuk seludang bunga

33 Bentuk ujung seludang bunga

34 Warna utama permukaan atas seludang bunga

35 Kilap permukaan atas seludang bunga

36 Jarak antara seludang bunga dengan pangkal tongkol (stipe)

37 Arah tumbuh tongkol (spadix) terhadap tangkai bunga

38 Bentuk tongkol

39 Panjang tongkol

40 Diameter bagian tengah-tengah tongkol

41 Warna utama pangkal tongkol

42 Warna utama ujung tongkol

5. Sifat dari masing-masing tanaman ditabulasikan ke dalam tabel untuk mempermudah dalam mencari hubungan kemiripannya menggunakan software MEGA5 (Tamura et al., 2011). Data karakter morfologi dari tanaman Anthurium yang ditemukan dianalisis dengan metode UPGMA (Unweighted Pair Group Method with Arithmetic Mean) menggunakan software MEGA5 (Molecular Evolutionary Genetics Analysis) version 5 (Tamura et al., 2011) untuk dicari hubungan kemiripannya.

\section{HASIL DAN PEMBAHASAN}

Hasil penelitian didapatkan 17 taksa Anthurium, yaitu: A. jenmanii Engl.; $A$. plowmanii Croat; $A$. crystallinum Linden \& Andre; A. nymphaeifolium K. 
Koch \& Bouché; A. pedatoradiatum ssp. helleborifolium (Schott) Croat; A. bonplandii ssp. guayanum (G.S. Bunting) Croat; 2 kultivar $A$. andicola Liebm., yaitu A. Andicola "Kuku Bima dan A. andicola "List Merah"; 6 kultivar $A$. andraeanum Linden, yaitu A. andraeanum "Amigo", A. andraeanum "White", A. andraeanum "Tropical", A. andraeanum "Safari", A. andraeanum "Renoir Pink", dan A. andraeanum "cv. 1"; 1 kultivar $A$. crassinervium (Jacq.) Schott, yaitu $A$. crassinervium "Crispimarginatum"; dan 2 kultivar $A$. hookeri Kunth, yaitu A. hookeri "Red Hookeri" Kunth dan A. hookeri "Garuda". Ketujuh belas OTU (Operational Taxonomic Unit/satuan taksonomi operasional) tersebut mempunyai beberapa ciri morfologi yang menjadi karakteristik masing-masing OTU. Deskripsi Anthurium yang ditemukan berdasarkan hasil pengamatan adalah sebagai berikut:

Anthurium pedatoradiatum ssp. helleborifolium Schott., Ann. Missouri Bot. Gard. 70(2): 343, 347-348. 1983. Tipe: tidak diketahui.

Sinonim: Anthurium helleborifolium Schott, Bonplandia 10(9-10): 148. 1862 (Breedlove, 1986).

Tanaman herba dengan tinggi $\pm 110 \mathrm{~cm}$, diameter batang \pm 3,6 cm; terdapat daun sisik (cataphyll) pada tiap ruasnya, tekstur daun sisik seperti selaput. Helaian daun berbentuk bangun jantung lebar, bagian terlebar berada di bawah tengah-tengah helaian daun; panjang 30-35 cm, lebar 25-27 $\mathrm{cm}$; pangkal helaian daun bertoreh, posisi torehan pada pangkal daun bebas; ujung helaian daun meruncing; tepi helaian daun berbagi menjari (7-11 segmen); permukaan helaian daun bagian atas mengkilap dan berwarna hijau, sedangkan permukaan helaian daun bagian bawah berwarna hijau terang; pertulangan daun menjari, berwarna hijau muda, kenampakannya terhadap helaian daun menonjol. Tangkai daun berwarna hijau muda, penampang melintangnya berbentuk bundar, tidak beralur; panjang 75$80 \mathrm{~cm}$, diameter $0,7-0,9 \mathrm{~cm}$. Tangkai bunga berwarna hijau muda; panjang $25-30 \mathrm{~cm}$, diameter $0,3-0,6 \mathrm{~cm}$. Seludang bunga berbentuk lanset, berwarna hijau; ujung seludang bunga runcing; panjang seludang bunga $10-11 \mathrm{~cm}$, bagian terlebar seludang bunga berukuran antara 2-3 cm; permukaan seludang bunga bagian atas kurang mengkilap; posisi seludang bunga berada di bawah helaian daun. Tongkol berbentuk silinder meruncing, arah tumbuh tegak terhadap tangkai bunga; panjang $12-14 \mathrm{~cm}$, diameter bagian tengah-tengah $\pm 0,7 \mathrm{~cm}$; ujung dan pangkal tongkol berwarna cokelat kehitaman, panjang stipe $\pm 0,3 \mathrm{~cm}$.

Distribusi: ditanam sebagai tanaman hias di Perumahan Griya Satria II, Jatisari, Kelurahan Sumampir, Purwokerto.

Catatan: Anthurium pedatoradiatum ssp. helleborifolium merupakan satu-satunya Anthurium yang ditemukan dengan tepi daun berbagi. Tanaman ini dikenal dengan nama Anthurium Walisongo (Kadir, 2007). Anthurium pedatoradiatum ssp. helleborifolium termasuk ke dalam seksi Schizoplacium (Croat dan Sheffer, 1983).

Anthurium andicola Liebm., Vidensk. Meddel. Naturhist. Foren. Kjøbenhavn 1849: 22. 1849. Tipe: Mexico: Veracruz: Santa María Applapatahua, Volcán Orizaba, 2500 m, Liebmann s.n.

Sinonim: Anthurium cucullatum K. Koch \& Sello, Index Seminum (B) 1853 (App.): 6. 1853; Anthurium macdougallii Matuda, Anales Inst. Biol. Univ. Nac. México 22: 373. 1952; Anthurium oaxacamonticola Matuda, Anales Inst. Biol. Univ. Nac. México 27: 344. 1957; Anthurium chochotlense Matuda, Cact. Suc. Mex. 20: 11. 1975 (Breedlove, 1986).

\section{A. andicola "Kuku Bima"}

Tanaman herba dengan tinggi $\pm 72 \mathrm{~cm}$, diameter batang \pm 3 $\mathrm{cm}$; sisik daun bertekstur seperti jala. Helaian daun berbentuk bangun anak panah, bagian terlebar berada di bawah tengah-tengah helaian daun; panjang 35-40 cm, lebar 27-30 cm; pangkal helaian daun bertoreh, posisi torehan daun saling menutupi; ujung helaian daun meruncing; tepi helaian daun berombak-ombak; permukaan helaian daun bagian atas tidak mengkilap (suram) dan berwarna hijau tua, sedangkan permukaan helaian daun bagian bawah berwarna hijau; pertulangan daun campuran, berwarna hijau muda, kenampakan tulang daun terhadap helaian daun menonjol. Tangkai daun berwarna hijau tua, penampang melintangnya berbentuk bangun bulan sabit, tidak beralur; panjang $34-37 \mathrm{~cm}$, diameter $1-1,2 \mathrm{~cm}$. Tangkai bunga berwarna hijau tua; panjang 95-100 cm, diameter 1,2-1,4 cm. Seludang bunga berbentuk lanset, berwarna hijau muda, tepi seludang bunga berwarna ungu; ujung seludang bunga meruncing; panjang seludang bunga $6-7 \mathrm{~cm}$, bagian terlebar seludang bunga berukuran antara 3-4 cm; permukaan seludang bunga bagian atas kurang mengkilap; posisi seludang bunga berada di atas helaian daun. Tongkol berbentuk silinder, arah tumbuh membentuk sudut tumpul terhadap tangkai bunga; panjang 25-27 cm, diameter bagian tengah-tengah $\pm 1,5 \mathrm{~cm}$; ujung dan pangkal tongkol berwarna ungu kemerahan, panjang stipe $\pm 0,5 \mathrm{~cm}$.

Distribusi: ditanam sebagai tanaman hias di sekitar Jln. Dr. Angka, Kelurahan Sokanegara, Purwokerto.

Catatan: A. andicola termasuk ke dalam seksi Belolonchium (Carlsen, 2011). Tanaman ini dikenal dengan nama Anthurium Corong 'Kuku Bima' (Kadir, 2007).

\section{A. andicola "List Merah"}

Tanaman herba dengan tinggi $\pm 80 \mathrm{~cm}$; diameter batang \pm 3 $\mathrm{cm}$; mempunyai daun sisik yang bertekstur seperti jala. Helaian daun berbentuk bangun anak panah, bagian terlebar berada di bawah tengah-tengah helaian daun; panjang 45$48 \mathrm{~cm}$, lebar 28-31 cm; pangkal helaian daun bertoreh, posisi torehan daun saling menutupi; ujung helaian daun meruncing; tepi helaian daun berombak- ombak, berwarna merah; permukaan helaian daun bagian atas tidak mengkilap (suram) dan berwarna hijau tua, sedangkan permukaan helaian daun bagian bawah berwarna hijau; pertulangan daun campuran, berwarna merah, kenampakan tulang daun terhadap helaian daun rata. Tangkai daun berwarna hijau muda, penampang melintangnya berbentuk bangun bulan sabit, tidak beralur; panjang 47-50 cm, diameter 0,8-0,9 cm. Tangkai bunga berwarna hijau muda; panjang $60-63 \mathrm{~cm}$, diameter $0,8-0,9 \mathrm{~cm}$. Seludang bunga berbentuk lanset, berwarna hijau muda, tepi seludang bunga berwarna ungu; ujung seludang bunga runcing; panjang seludang bunga $9-10 \mathrm{~cm}$, bagian terlebar seludang bunga berukuran antara 5-6 cm; permukaan seludang bunga bagian atas kurang mengkilap; posisi seludang bunga sejajar helaian daun. Tongkol berbentuk silinder meruncing, arah tumbuh membentuk sudut tumpul terhadap tangkai bunga; panjang 28-30 cm, diameter bagian tengah-tengah $\pm 1,5 \mathrm{~cm}$; ujung tongkol berwarna ungu dan pangkal tongkol berwarna ungu kemerahan, panjang stipe $\pm 1,5 \mathrm{~cm}$.

Distribusi: ditanam sebagai tanaman hias di Kelurahan Bobosan, Purwokerto.

Catatan: A. andicola "List Merah" mempunyai helaian daun lebih besar dan tongkol lebih panjang dibandingkan dengan $A$. andicola "Kuku Bima". Tanaman ini dikenal dengan nama Anthurium Corong "List Merah" (Kadir, 2007). 
Anthurium crystallinum Linden \& André, Cat. Gén. 90: t. 128. 1873. Tipe: Peru, Wallis s.n.

Sinonim: Anthurium crystallinum fo. peltifolium Engl., Pflanzenr., IV, 23B: 198. 1905; Anthurium killipianum L.Uribe, Caldasia 5: 77. 1948 (Bailey dan Bailey, 1976).

Tanaman herba dengan tinggi $\pm 35 \mathrm{~cm}$, diameter batang \pm 3 $\mathrm{cm}$; daun sisik pada ruas-ruas batang bersifat halus (seperti selaput). Helaian daun berbentuk bangun jantung lebar, bagian terlebar berada tengah-tengah helaian daun; panjang 29-33 cm, lebar 25-26 cm; pangkal helaian daun bertoreh, posisi torehan daun saling menutupi; ujung helaian daun meruncing; tepi helaian daun rata; tekstur permukaan helaian daun bagian atas seperti beludru dan tidak mengkilap (suram) serta berwarna hijau tua, sedangkan permukaan bagian bawah helaian daun berwarna hijau; pertulangan daun campuran, berwarna hijau muda, kenampakan tulang daun terhadap helaian daun menonjol. Tangkai daun berwarna hijau tua, pada pangkal tangkai daun berwarna agak keunguan, penampang melintangnya berbentuk bangun bulan sabit, tidak beralur; panjang 20-22 $\mathrm{cm}$, diameter $0,5-0,7 \mathrm{~cm}$. Tangkai bunga berwarna hijau tua; panjang $48-52 \mathrm{~cm}$, diameter $0,7-0,8 \mathrm{~cm}$. Seludang bunga berbentuk lanset, berwarna hijau muda; ujung seludang bunga meruncing; panjang seludang bunga $8-9 \mathrm{~cm}$, bagian terlebar seludang bunga berukuran $\pm 2,5 \mathrm{~cm}$; permukaan seludang bunga bagian atas kurang mengkilap; posisi seludang bunga di atas helaian daun. Tongkol berbentuk silinder, arah tumbuh tongkol tegak terhadap tangkai bunga; panjang $18-20 \mathrm{~cm}$, diameter bagian tengahtengah $\pm 0,7 \mathrm{~cm}$; ujung dan pangkal tongkol berwarna kuning, panjang stipe $\pm 2 \mathrm{~cm}$.

Distribusi: ditanam sebagai tanaman hias di Pengasinan, Kelurahan Tanjung, Purwokerto.

Catatan: Tanaman ini dikenal sebagai tanaman Kuping Gajah (Rukmana, 1997). Croat dan Sheffer (1983), menggolongkan A. crystallinum ke dalam seksi Cardiolonchium.

Anthurium nymphaeifolium K. Koch \& Bouche, Index Sem. (Berlin) (App.): 9. 1854. Tipe: Venezuela; Regionibus Caracasanis, Wagener s.n.

Sinonim: Anthurium cardiophyllum K. Koch \& Augustin, Ind. Sem. Hort. Berol. App. 9. 1854; Anthurium fucatum Schott, Oesterr. Bot. Wochenbl. 8: 387. 1858; Anthurium cochleatum Moritz ex Schott, Prodr. Syst. Aroid.: 499. 1860; Anthurium inamoenum Schott, Prodr. Syst. Aroid.: 504. 1860 (Bunting, 1979).

Tanaman herba dengan tinggi $\pm 55 \mathrm{~cm}$, diameter batang \pm $2,7 \mathrm{~cm}$; tekstur daun sisik halus (seperti selaput). Helaian daun berbentuk bangun jantung lebar, bagian terlebar berada tengah- tengah atau sedikit di bawah tengah-tengah helaian daun; panjang 31-35 cm, lebar 25-27 cm; pangkal helaian daun bertoreh, posisi torehan daun bersentuhan; ujung helaian daun runcing; tepi helaian daun rata; permukaan helaian daun bagian atas tidak mengkilap (suram) dan berwarna hijau, sedangkan permukaan helaian daun bagian bawah berwarna hijau muda; pertulangan daun campuran, berwarna hijau kekuningan, kenampakan tulang daun terhadap helaian daun rata. Tangkai daun berwarna hijau tua, penampang melintangnya berbentuk bulat, tidak beralur; panjang $43-49 \mathrm{~cm}$, diameter $0,8-0,9 \mathrm{~cm}$. Tangkai bunga berwarna hijau tua; panjang $31-33 \mathrm{~cm}$, diameter \pm $0,6 \mathrm{~cm}$. Seludang bunga berbentuk jorong, berwarna putih; ujung seludang bunga meruncing; panjang seludang bunga 8-9 cm, bagian terlebar seludang bunga berukuran 4-4,5 $\mathrm{cm}$; intensitas kilap permukaan seludang bunga bagian atas sedang; posisi seludang bunga berada di bawah helaian daun. Tongkol berbentuk silinder, arah tumbuh tongkol tegak terhadap tangkai bunga; panjang 10-11 cm, diameter bagian tengah-tengah $\pm 1,7 \mathrm{~cm}$; ujung dan pangkal tongkol berwarna merah muda, panjang stipe $\pm 0,5 \mathrm{~cm}$.

Distribusi: dibudidayakan pada salah satu Nursery di Desa Rempoah, Baturraden.

Catatan: A. nymphaeifolium merupakan Anthurium berseludang bunga indah. Croat dan Sheffer (1983), menggolongkannya ke dalam seksi Calomystrium.

Anthurium andraeanum Linden ex André, Ill. Hort. 24: 43. 1877. Tipe: Colombia, Linden s.n.

Sinonim: Anthurium venustum Sodiro, Revista Chilena Hist. Nat. 9: 257. 1905 (Bailey dan Bailey, 1976).

\section{A. andraeanum "Amigo"}

Tanaman herba dengan tinggi $\pm 50 \mathrm{~cm}$, diameter batang \pm $3,5 \mathrm{~cm}$, tekstur daun sisik halus (seperti selaput). Helaian daun berbentuk bangun jantung lebar, bagian terlebar berada di tengah-tengah helaian daun; panjang $28-34 \mathrm{~cm}$, lebar 20-22 cm; pangkal helaian daun bertoreh, posisi torehan daun saling menutupi; ujung helaian daun meruncing; tepi helaian daun rata; permukaan helaian daun bagian atas tidak mengkilap (suram) dan berwarna hijau tua, sedangkan permukaan helaian daun bagian bawah berwarna hijau; pertulangan daun campuran, berwarna hijau muda, kenampakan tulang daun terhadap helaian daun rata. Tangkai daun berwarna hijau tua, penampang melintangnya berbentuk bulat, tidak beralur; panjang 35-43 $\mathrm{cm}$, diameter $\pm 0,6 \mathrm{~cm}$. Tangkai bunga berwarna merah keunguan; panjang 55-61 cm, diameter 0,8-0,9 cm. Seludang bunga berbentuk menjantung, berwarna hijau, pada bagian pangkal seludang bunga berwarna sedikit kemerah-merahan; ujung seludang bunga meruncing; panjang seludang bunga $37-40 \mathrm{~cm}$, bagian terlebar mengkilap; posisi seludang bunga berada di atas helaian daun. Tongkol berbentuk silinder, arah tumbuh tongkol membentuk sudut tumpul terhadap tangkai bunga; panjang 15-17 cm, diameter bagian tengah-tengah $\pm 2 \mathrm{~cm}$; ujung dan pangkal tongkol berwarna hijau kekuningan, panjang stipe \pm $0,6 \mathrm{~cm}$.

Distribusi: dibudidayakan di kebun pemeliharaan Balai Benih Tanaman Pangan dan Hortikultura, Baturraden.

Catatan: termasuk ke dalam kultivar $A$. andraeanum yang berseludang bunga 2 warna. Croat dan Sheffer (1983) menggolongkan A. andraeanum ke dalam seksi Calomystrium.

\section{A. andraeanum "White"}

Tanaman herba dengan tinggi $\pm 35 \mathrm{~cm}$, diameter batang \pm $1,2 \mathrm{~cm}$, tekstur daun sisik halus (seperti selaput). Helaian daun berbentuk bangun jantung sempit, bagian terlebar berada di tengah-tengah helaian daun; panjang $25-26 \mathrm{~cm}$, lebar 12-13 cm; pangkal helaian daun bertoreh, posisi torehan daun bebas; ujung helaian daun meruncing; tepi helaian daun rata; permukaan helaian daun bagian atas tidak mengkilap (suram) dan berwarna hijau, sedangkan permukaan helaian daun bagian bawah berwarna hijau muda; pertulangan daun campuran, berwarna hijau muda, kenampakan tulang daun terhadap helaian daun rata. Tangkai daun berwarna hijau muda, penampang melintangnya berbentuk bulat, tidak beralur; panjang 27-31 $\mathrm{cm}$, diameter $0,3-0,4 \mathrm{~cm}$. Tangkai bunga berwarna hijau muda; panjang $47-48 \mathrm{~cm}$, diameter $\pm 0,5 \mathrm{~cm}$. Seludang bunga berbentuk menjantung, berwarna putih; ujung seludang bunga meruncing; panjang seludang bunga 11-12 $\mathrm{cm}$, bagian terlebar seludang bunga berukuran 8-9 cm; 
permukaan seludang bunga bagian sangat mengkilap; posisi seludang bunga berada di atas helaian daun. Tongkol berbentuk silinder, arah tumbuh tongkol membentuk sudut tumpul terhadap tangkai bunga; panjang 6-8 $\mathrm{cm}$, diameter bagian tengah-tengah $\pm 1,2 \mathrm{~cm}$; ujung tongkol berwarna putih, sedangkan pangkal tongkol berwarna kuning, panjang stipe $\pm 0,3 \mathrm{~cm}$.

Distribusi: dibudidayakan di kebun pemeliharaan Balai Benih Tanaman Pangan dan Hortikultura, Baturraden.

Catatan: termasuk ke dalam kultivar A. andraeanum yang berseludang bunga putih.

\section{A. andraeanum "Tropical"}

Tanaman herba dengan tinggi $\pm 30 \mathrm{~cm}$, diameter batang \pm $0,8 \mathrm{~cm}$, tekstur daun sisik halus (seperti selaput). Helaian daun berbentuk bangun jantung sempit, bagian terlebar berada di bawah tengah-tengah helaian daun; panjang 20$25 \mathrm{~cm}$, lebar 9-10 cm; pangkal helaian daun bertoreh, posisi torehan daun bebas; ujung helaian daun meruncing; tepi helaian daun rata; permukaan helaian daun bagian atas tidak mengkilap (suram) dan berwarna hijau, sedangkan permukaan helaian daun bagian bawah berwarna hijau muda; pertulangan daun campuran, berwarna hijau muda, kenampakan tulang daun terhadap helaian daun rata. Tangkai daun berwarna hijau tua, penampang melintangnya berbentuk bulat, tidak beralur; panjang $20-22 \mathrm{~cm}$, diameter $\pm 0,4 \mathrm{~cm}$. Tangkai bunga berwarna hijau muda kemerahan; panjang $33-35 \mathrm{~cm}$, diameter $\pm 0,5 \mathrm{~cm}$. Seludang bunga berbentuk menjantung, berwarna merah; ujung seludang bunga meruncing; panjang seludang bunga 8-9 $\mathrm{cm}$, bagian terlebar seludang bunga berukuran 6-7 $\mathrm{cm}$; permukaan seludang bunga bagian atas sangat mengkilap; posisi seludang bunga berada di atas helaian daun. Tongkol berbentuk silinder, arah tumbuh tongkol membentuk sudut tumpul terhadap tangkai bunga; panjang 6-7 $\mathrm{cm}$, diameter bagian tengah-tengah $\pm 1 \mathrm{~cm}$; ujung tongkol berwarna putih, sedangkan pangkal tongkol berwarna kuning, panjang stipe $\pm 0,1 \mathrm{~cm}$.

Distribusi: ditanam sebagai tanaman hias di Kelurahan Purwokerto Lor, Purwokerto.

Catatan: termasuk ke dalam kultivar A. andraeanum yang berseludang bunga merah.

\section{A. andraeanum "Safari"}

Tanaman herba dengan tinggi $\pm 40 \mathrm{~cm}$, diameter batang \pm $1,5 \mathrm{~cm}$, tekstur daun sisik halus (seperti selaput). Helaian daun berbentuk bangun jantung sempit, bagian terlebar berada di bawah tengah-tengah helaian daun; panjang 28$30 \mathrm{~cm}$, lebar 13-14 cm; pangkal helaian daun bertoreh, posisi torehan daun bersentuhan; ujung helaian daun meruncing; tepi helaian daun rata; permukaan helaian daun bagian atas tidak mengkilap (suram) dan berwarna hijau, sedangkan permukaan helaian daun bagian bawah berwarna hijau muda; pertulangan daun campuran, berwarna hijau kekuningan, kenampakan tulang daun terhadap helaian daun rata. Tangkai daun berwarna hijau tua kemerahan, penampang melintangnya berbentuk bulat, tidak beralur; panjang $29-30 \mathrm{~cm}$, diameter $\pm 0,5 \mathrm{~cm}$. Tangkai bunga berwarna merah; panjang $25-27 \mathrm{~cm}$, diameter $\pm 0,5$ $\mathrm{cm}$. Seludang bunga berbentuk menjantung, berwarna merah dengan urat-urat putih; ujung seludang bunga meruncing; panjang seludang bunga $10-11 \mathrm{~cm}$, bagian terlebar seludang bunga berukuran 10-11 cm; permukaan seludang bunga bagian mengkilap; posisi seludang bunga sejajar helaian daun. Tongkol berbentuk silinder meruncing, arah tumbuh tongkol tegak terhadap tangkai bunga; panjang 6-7 cm, diameter bagian tengah- tengah $\pm 1,2 \mathrm{~cm}$; ujung dan pangkal tongkol berwarna merah, panjang stipe $\pm 0,2 \mathrm{~cm}$.

Distribusi: dibudidayakan pada salah satu Nursery di Desa Pandak, Baturraden.

Catatan: termasuk ke dalam kultivar A. andraeanum yang berseludang bunga merah dan termasuk kultivar yang langka.

\section{A. andraeanum "Renoir Pink"}

Tanaman herba dengan tinggi $\pm 35 \mathrm{~cm}$, diameter batang \pm $0,8 \mathrm{~cm}$, tekstur daun sisik halus (seperti selaput). Helaian daun berbentuk bangun jantung sempit, bagian terlebar berada di bawah tengah-tengah helaian daun; panjang 25$27 \mathrm{~cm}$, lebar 14-15 cm; pangkal helaian daun bertoreh, posisi torehan daun bebas tetapi ada beberapa yang bersentuhan; ujung helaian daun meruncing; tepi helaian daun rata; permukaan helaian daun bagian atas tidak mengkilap (suram) dan berwarna hijau, sedangkan permukaan helaian daun bagian bawah berwarna hijau muda; pertulangan daun campuran, berwarna hijau muda, kenampakan tulang daun terhadap helaian daun rata. Tangkai daun berwarna hijau tua, penampang melintangnya berbentuk bulat, tidak beralur; panjang $25-31 \mathrm{~cm}$, diameter $\pm 0,5 \mathrm{~cm}$. Tangkai bunga berwarna merah; panjang 25-27 $\mathrm{cm}$, diameter $\pm 0,5 \mathrm{~cm}$. Seludang bunga berbentuk menjantung, berwarna merah muda; ujung seludang bunga meruncing; panjang seludang bunga $6-7 \mathrm{~cm}$, bagian terlebar seludang bunga berukuran $7-8 \mathrm{~cm}$; permukaan seludang bunga bagian atas mengkilap; posisi seludang bunga sejajar helaian daun. Tongkol berbentuk silinder, arah tumbuh tongkol tegak terhadap tangkai bunga; panjang 6-7 cm, diameter bagian tengah-tengah $\pm 1 \mathrm{~cm}$; ujung dan pangkal tongkol berwarna merah muda, panjang stipe $\pm 0,2 \mathrm{~cm}$.

Distribusi: dibudidayakan pada salah satu Nursery di Desa Rempoah, Baturraden.

Catatan: termasuk ke dalam kultivar A. andraeanum yang berseludang bunga merah muda.

\section{A. andraeanum "cv. 1"}

Tanaman herba dengan tinggi $\pm 100 \mathrm{~cm}$, diameter batang \pm 2 $\mathrm{cm}$, tekstur daun sisik halus (seperti selaput). Helaian daun berbentuk bangun jantung sempit, bagian terlebar berada di bawah tengah-tengah helaian daun; panjang 38-41 cm, lebar 14-16 cm; pangkal helaian daun bertoreh, posisi torehan daun bebas; ujung helaian daun meruncing; tepi helaian daun rata; permukaan helaian daun bagian atas tidak mengkilap (suram) dan berwarna hijau tua, sedangkan permukaan helaian daun bagian bawah berwarna hijau; pertulangan daun campuran, berwarna hijau tua, kenampakan tulang daun terhadap helaian daun rata. Tangkai daun berwarna hijau tua keunguan, penampang melintangnya berbentuk bulat, tidak beralur; panjang 64$66 \mathrm{~cm}$, diameter 1-1,2 cm. Tangkai bunga berwarna hijau tua keunguan; panjang $75-80 \mathrm{~cm}$, diameter $\pm 0,8 \mathrm{~cm}$. Seludang bunga berbentuk menjantung, berwarna merah; ujung seludang bunga meruncing; panjang seludang bunga 9-10 cm, bagian terlebar seludang bunga berukuran $8-9 \mathrm{~cm}$; permukaan seludang bunga bagian atas mengkilap; posisi seludang bunga di atas helaian daun. Tongkol berbentuk silinder meruncing, arah tumbuh tongkol membentuk sudut tumpul terhadap tangkai bunga; panjang 10-11 cm, diameter bagian tengah-tengah $\pm 1,6 \mathrm{~cm}$; ujung tongkol berwarna hijau, sedangkan pangkal tongkol berwarna putih, panjang stipe $\pm 0,5 \mathrm{~cm}$.

Distribusi: dibudidayakan di kebun pemeliharaan Balai Benih Tanaman Pangan dan Hortikultura, Baturraden.

Catatan: kultivar ini mempunyai tangkai daun yang 
panjang dibandingkan dengan kultivar A. andraeanum yang lain.

Anthurium crassinervium (Jacq.) Schott, Wiener Z. Kunst 1829 (3): 828. 1829. Tipe: Colombia; Boyaca $2600 \mathrm{~m}$, Fernández-Alonso \& et al., 14364 (COL).

Sinonim: Anthurium ellipticum K. Koch \& Bouché, Index Seminum (Berlin) App. 6. 1853; Pothos crassinervius Jacq., Collectanea 4: 122. 1791 (Croat, 1991).

\section{A. crassinervium "Crispimarginatum"}

Tanaman herba dengan tinggi $\pm 130 \mathrm{~cm}$, diameter batang \pm 5 $\mathrm{cm}$; daun sisik pada ruas- ruas batang bersifat kasar (seperti jala). Helaian daun berbentuk bangun lanset, bagian terlebar berada di tengah-tengah helaian daun; panjang 90-100 cm, lebar 15-17 cm; pangkal helaian daun runcing; ujung helaian daun runcing; tepi helaian daun berombak-ombak; permukaan helaian daun bagian atas tidak mengkilap (suram) dan berwarna hijau tua, permukaan helaian daun bagian bawah juga berwarna hijau tua; pertulangan daun menyirip, berwarna hijau tua, kenampakan tulang daun terhadap helaian daun menonjol. Tangkai daun berwarna hijau tua, penampang melintangnya bersegi empat, tidak beralur; panjang 14-16 cm, diameter 1,5-1,7 cm. Tangkai bunga berwarna hijau tua; panjang $80-86 \mathrm{~cm}$, diameter 1,4$1,7 \mathrm{~cm}$. Seludang bunga berbentuk lanset, berwarna hijau muda, tepi seludang bunga berwarna ungu; ujung seludang bunga meruncing; panjang seludang bunga 17-19 cm, bagian terlebar seludang bunga berukuran $\pm 2,5 \mathrm{~cm}$; permukaan seludang bunga bagian atas kurang mengkilap; posisi seludang bunga sejajar helaian daun. Tongkol berbentuk silinder meruncing, arah tumbuh tongkol membentuk sudut tumpul terhadap tangkai bunga; panjang 23-26 cm, diameter bagian tengah-tengah $\pm 2 \mathrm{~cm}$; ujung dan pangkal tongkol berwarna cokelat, panjang stipe $\pm 0,5 \mathrm{~cm}$.

Distribusi: ditanam sebagai tanaman hias di Kelurahan Sokanegara, Purwokerto.

Catatan: A. crassinervium "Crispimarginatum" merupakan satu-satunya Anthurium yang ditemukan dengan bentuk helaian daun lanset memanjang. Menurut Kadir (2007), tanaman ini dikenal dengan nama Anthurium Keris. Menurut Croat (1991), A. crassinervium termasuk ke dalam seksi Pachyneurium.

Anthurium hookeri Kunth, Enum. Pl. 3: 74. 1841. Tipe: Venezuela; Monagas 750-900 m, G.S. Bunting 2632 (MY).

Sinonim: Anthurium huegelii Schott, Oesterr. Bot. Wochenbl. 5: 83. 1855; Anthurium neglectum Miq., Cat. Hort. Amstelod. 1853 (Mayo, 1982).

\section{A. hookeri "Red Hookeri"}

Tanaman herba dengan tinggi $\pm 55 \mathrm{~cm}$, diameter batang \pm $3,5 \mathrm{~cm}$; daun sisik pada ruas-ruas batang bersifat kasar (seperti jala). Helaian daun berbentuk bangun jorong, bagian terlebar berada di tengah-tengah helaian daun; panjang 40-43 cm, lebar 17-18 cm; pangkal helaian daun rata hingga membulat; ujung helaian daun meruncing; tepi helaian daun berombak-ombak; permukaan helaian daun bagian atas mengkilap dan berwarna hijau, sedangkan permukaan helaian daun bagian bawah berwarna hijau muda; pertulangan daun menyirip, berwarna hijau kekuningan, kenampakan tulang daun terhadap helaian daun menonjol. Tangkai daun berwarna merah keunguan, penampang melintangnya bersegi empat, tidak beralur; panjang 5-7 cm, diameter 1,2-1,4 cm. Tangkai bunga berwarna merah keunguan; panjang 36-39 cm, diameter $0,6-0,9 \mathrm{~cm}$. Seludang bunga berbentuk lanset, berwarna merah keunguan; ujung seludang bunga meruncing; panjang seludang bunga $12-15 \mathrm{~cm}$, bagian terlebar seludang bunga berukuran 3-3,5 cm; permukaan seludang bunga bagian kurang mengkilap; posisi seludang bunga di bawah helaian daun. Tongkol berbentuk silinder, arah tumbuh tongkol tegak terhadap tangkai bunga; panjang 13-15 cm, diameter bagian tengah-tengah $\pm 1,8 \mathrm{~cm}$; ujung dan pangkal tongkol berwarna merah keunguan, panjang stipe $\pm 1,5 \mathrm{~cm}$.

Distribusi: ditanaman sebagai tanaman hias di Kelurahan Mersi, Purwokerto.

Catatan: A. hookeri "Red Hookeri" mempunyai ciri khas berupa tangkai daun yang berwarna merah keunguan. Engler (1905), menggolongkan A. hookeri ke dalam seksi Pachyneurium.

\section{A. hookeri "Garuda"}

Tanaman herba dengan tinggi $\pm 60 \mathrm{~cm}$, diameter batang \pm $3,5 \mathrm{~cm}$; daun sisik pada ruas-ruas batang bersifat kasar (seperti jala). Helaian daun berbentuk jorong, bagian terlebar berada tengah-tengah helaian daun; panjang 73-75 $\mathrm{cm}$, lebar 25-26 cm; pangkal helaian daun rata hingga berlekuk; ujung helaian daun meruncing; tepi helaian daun berombak- ombak; permukaan helaian daun bagian atas mengkilap dan berwarna hijau, permukaan helaian daun bagian bawah juga berwarna hijau; pertulangan daun menyirip, berwarna hijau muda, kenampakan tulang daun terhadap helaian daun menonjol. Tangkai daun berwarna hijau tua, penampang melintangnya bersegi empat, tidak beralur; panjang 16-17 cm, diameter 1,5-1,8 cm. Tangkai bunga berwarna hijau tua keunguan; panjang 42-47 cm, diameter 1,1-1,4 cm. Seludang bunga berbentuk lanset, berwarna hijau muda; ujung seludang bunga meruncing; panjang seludang bunga $16-18 \mathrm{~cm}$, bagian terlebar seludang bunga berukuran 5-6 cm; permukaan seludang bunga bagian kurang mengkilap; posisi seludang bunga di bawah helaian daun. Tongkol berbentuk silinder meruncing, arah tumbuh tongkol tegak terhadap tangkai bunga; panjang 19$20 \mathrm{~cm}$, diameter bagian tengah $\pm 1,5 \mathrm{~cm}$; ujung dan pangkal tongkol berwarna ungu, panjang stipe $\pm 1 \mathrm{~cm}$.

Distribusi: dibudidayakan di Greenhouse Balai Benih Tanaman Pangan dan Hortikultura Kabupaten Banyumas

Catatan: kultivar ini dikenal dengan nama "Garuda" karena A. hookeri "Garuda" mempunyai helaian daun seperti paruh Garuda.

Anthurium bonplandii ssp. guayanum (G.S. Bunting) Croat, Ann. Missouri Bot. Gard. 78(3):614, f. 60-62. 1991. Tipe: tidak diketahui.

Sinonim: Anthurium corocoroense G.S. Bunting, Phytologia 64(6): 462. 1988 (Croat, 1991)

Tanaman herba dengan tinggi $\pm 110 \mathrm{~cm}$, diameter batang \pm 4 $\mathrm{cm}$; daun sisik pada ruas-ruas batang bersifat kasar (seperti jala). Helaian daun berbentuk bangun spathula (sudip), bagian terlebar berada di atas tengah-tengah helaian daun; panjang $110-115 \mathrm{~cm}$, lebar $48-50 \mathrm{~cm}$; pangkal helaian daun runcing; ujung helaian daun membulat; tepi helaian daun berombak-ombak; permukaan helaian daun bagian atas mengkilap dan berwarna hijau gelap, sedangkan permukaan helaian daun bagian bawah berwarna hijau; pertulangan daun menyirip, berwarna hijau tua, kenampakan tulang daun terhadap helaian daun menonjol. Tangkai daun berwarna hijau muda, penampang melintangnya berbentuk bangun bulan sabit, beralur; panjang $15-20 \mathrm{~cm}$, diameter 2,6-3,1 cm. Tangkai bunga berwarna merah keunguan; panjang 25-29 $\mathrm{cm}$, diameter 0,8-1,3 cm. Seludang bunga berbentuk lanset, berwarna merah keunguan; ujung seludang bunga meruncing; panjang seludang bunga 18-20 
$\mathrm{cm}$, bagian terlebar seludang bunga berukuran 5-6 cm; permukaan seludang bunga bagian kurang mengkilap; posisi seludang bunga di bawah helaian daun. Tongkol berbentuk bulat telur memanjang, arah tumbuh tongkol tegak terhadap tangkai bunga; panjang 23-28 cm, diameter bagian tengahtengah $\pm 3 \mathrm{~cm}$; ujung dan pangkal tongkol berwarna ungu, panjang stipe $\pm 3 \mathrm{~cm}$.

Distribusi: ditanam sebagai tanaman hias di Desa Pandak, Baturraden.

Catatan: Anthurium bonplandii ssp. guayanum termasuk ke dalam seksi Pachyneurium (Croat, 1991).

Anthurium jenmanii Engl., Pflanzenr., IV, 23B: 72 (1905). Tipe: Guyana; Essequibo, Jenman 5760 (K).

Sinonim: Anthurium trinitatis Engl., Pflanzenr., IV, 23B: 73. 1905; Anthurium englerianum G.S.Bunting, Acta Bot. Venez. 10: 270. 1975 (Croat, 1991).

Tanaman herba dengan tinggi $\pm 75 \mathrm{~cm}$, diameter batang \pm 2,3 cm; daun sisik pada ruas- ruas batang bersifat kasar (seperti jala). Helaian daun berbentuk bangun spathula (sudip), bagian terlebar berada di atas tengah-tengah helaian daun; panjang 58-62 cm, lebar 25-30 cm; pangkal helaian daun runcing; ujung helaian daun tumpul; tepi helaian daun rata; permukaan bagian atas helaian daun mengkilap dan berwarna hijau, permukaan bagian bawah helaian daun juga berwarna hijau; pertulangan daun menyirip, berwarna hijau muda, kenampakan tulang daun terhadap helaian daun menonjol. Tangkai daun berwarna hijau muda, penampang melintangnya berbentuk bangun bulan sabit, beralur; panjang 9-13 cm, diameter 1,3-1,6 cm. Tangkai bunga berwarna hijau muda, bagian pangkal berwarna agak keunguan; panjang 60-63 cm, diameter $1-1,3 \mathrm{~cm}$. Seludang bunga berbentuk lanset, berwarna merah keunguan; ujung seludang bunga meruncing; panjang seludang bunga $8-9 \mathrm{~cm}$, bagian terlebar seludang bunga berukuran $2-2,5 \mathrm{~cm}$; permukaan bagian atas seludang bunga kurang mengkilap; posisi seludang bunga di bawah helaian daun. Tongkol berbentuk silinder, arah tumbuh tongkol membentuk sudut tumpul terhadap tangkai bunga; panjang 10-12 cm, diameter bagian tengah-tengah $\pm 1,4 \mathrm{~cm}$; ujung dan pangkal tongkol berwarna ungu kehitaman, panjang stipe $\pm 2 \mathrm{~cm}$.

Distribusi : dibudidayakan pada salah satu Nursery di Desa Rempoah, Baturraden.

Catatan : A. jenmanii termasuk ke dalam seksi Pachyneurium (Croat, 1991).

Anthurium plowmanii Croat, Candollea 42: 811. 1987. Tipe: Brazil; Amazonas; Mpo. Manaus; Chacaras de Taruma, Croat 53563 (MO).

Sinonim: tidak ada (Croat, 1991).

Tanaman herba dengan tinggi $\pm 130 \mathrm{~cm}$, diameter batang \pm $5 \mathrm{~cm}$; daun sisik pada ruas-ruas batang bersifat kasar (seperti jala). Helaian daun berbentuk bangun belah ketupat, bagian terlebar berada di atas tengah-tengah helaian daun; panjang 75-83 cm, lebar $35-40 \mathrm{~cm}$; pangkal helaian daun runcing; ujung helaian daun meruncing; tepi helaian daun berombak-ombak; permukaan helaian daun bagian atas tidak mengkilap dan berwarna hijau tua, permukaan helaian daun bagian bawah juga berwarna hijau tua; pertulangan daun menyirip, berwarna hijau tua, kenampakan tulang daun terhadap helaian daun menonjol. Tangkai daun berwarna hijau tua, penampang melintangnya berbentuk bangun bulan sabit, tidak beralur; panjang 15$19 \mathrm{~cm}$, diameter 2,9-3,1 cm. Tangkai bunga berwarna hijau tua; panjang 6-7 cm, diameter $2,2-2,7 \mathrm{~cm}$. Seludang bunga berbentuk jorong, berwarna hijau muda, bagian ujung seludang bunga berwarna merah keunguan; ujung seludang bunga meruncing; panjang seludang bunga 32-35 $\mathrm{cm}$, bagian terlebar seludang bunga berukuran 8-9 cm; permukaan seludang bunga bagian atas kurang mengkilap; posisi seludang bunga di bawah helaian daun. Tongkol berbentuk bulat telur memanjang, arah tumbuh tongkol tegak terhadap tangkai bunga; panjang 38-43 cm, diameter bagian tengah-tengah $\pm 5 \mathrm{~cm}$; ujung dan pangkal tongkol berwarna ungu, panjang stipe $\pm 3 \mathrm{~cm}$.

Distribusi: ditemukan sebagai tanaman hias di Kelurahan Tanjung, Purwokerto.

Catatan: Croat (1991), menggolongkan A. plowmanii ke dalam seksi Pachyneurium.

Hubungan kemiripan antar Anthurium yang ditemukan di beberapa lokasi di eks-Kotatip Purwokerto dan Baturraden, serta Balai Benih Tanaman Pangan dan Hortikultura (B2TPH) Kabupaten Banyumas mempunyai koefisien dissimilaritas antara 0,181-2,892. Menurut Rohlf (1993) dalam Karamura (1998), koefisien dissimilaritas menunjukkan angka perbedaan antar OTU yang diteliti. Semakin kecil koefisien dissimilaritasnya maka semakin dekat hubungan kemiripannya dan semakin besar koefisien dissimilaritasnya maka semakin jauh hubungan kemiripannya. Hubungan kemiripan terdekat adalah antara A. andraeanum "Renoir Pink" dan $A$. andraeanum "Safari" dengan koefisien dissimilaritas 0,181 . Hal ini terlihat dari persamaan sifat morfologi kedua Anthurium tersebut, yaitu tinggi tanaman antara $35-40 \mathrm{~cm}$; daun sisik bersifat seperti selaput (halus); bentuk helaian daun menjantung sempit, panjang antara 25-30 cm dan lebar antara 13-15 cm, ujung helaian daun meruncing, pangkal helaian daun bertoreh, tepi helaian daun rata, intensitas warna hijau pada permukaan helaian daun bagian atas sedang; pertulangan daun campuran (menjarimenyirip), pertulangan daun rata terhadap helaian daun; penampang melintang tangkai daun bulat, panjang antara $25-31 \mathrm{~cm}$, diameter $\pm 0,5 \mathrm{~cm}$; seludang bunga menjantung, posisi seludang bunga sejajar helaian daun, kilap permukaan seludang bunga bagian atas sedang, ujung seludang bunga meruncing; tongkol berbentuk silinder, panjang 6-7 cm, arah tumbuh tongkol tegak terhadap tangkai bunga, dan panjang stipe $\pm 0,2 \mathrm{~cm}$. Hubungan kemiripan terjauh adalah antara $A$. bonplandii ssp. guayanum dan $A$. andraeanum "Tropical" dengan koefisien dissimilaritas 2,892. Persamaan sifat morfologi kedua Anthurium tersebut hanya pada panjang tangkai daun yaitu antara $15-20 \mathrm{~cm}$ dan bentuk ujung seludang bunga yaitu meruncing.

Hasil analisis hubungan kemiripan antar Anthurium menggunakan metode UPGMA dengan software MEGA5 diperoleh fenogram seperti yang ditampilkan pada Gambar 1. Berdasarkan Gambar 1, ketujuh belas OTU tersebut dapat dikelompokkan menjadi 4 kelompok. Kelompok I terdiri atas A. andraeanum "Renoir Pink", A. andraeanum "Safari", A. andraeanum "White", A. andraeanum "Tropical", A. andraeanum "cv. 
1", A. andraeanum "Amigo", dan A. nymphaeifolium. Kelompok II terdiri atas $A$. pedatoradiatum, $A$. crystallinum, A. andicola "Kuku Bima", dan A. andicola "List Merah". Kelompok III terdiri atas $A$. crassinervium "Crispimarginatum" dan A. plowmanii. Kelompok IV terdiri atas A. hookeri "Garuda", $A$. hookeri "Red Hookeri", A. bonplandii ssp. guayanum, dan A. jenmanii.

Tabel 2. Matriks koefisien dissimilaritas antar Anthurium Schott yang diteliti

\begin{tabular}{|c|c|c|c|c|c|c|c|c|c|c|c|c|c|c|c|c|}
\hline & $\mathrm{A}$ & B & $\mathrm{C}$ & $\mathrm{D}$ & $\mathrm{E}$ & $F$ & $G$ & $\mathrm{H}$ & I & $\mathrm{J}$ & $\mathrm{K}$ & $\mathrm{L}$ & M & $\mathrm{N}$ & 0 & $\mathrm{P}$ \\
\hline B & 0.279 & & & & & & & & & & & & & & & \\
\hline $\mathrm{C}$ & 0.593 & 0.870 & & & & & & & & & & & & & & \\
\hline D & 0.499 & 0.678 & 0.242 & & & & & & & & & & & & & \\
\hline $\mathrm{E}$ & 1.479 & 1.479 & 0.484 & 0.559 & & & & & & & & & & & & \\
\hline $\mathrm{F}$ & 1.483 & 1.150 & 0.550 & 0.467 & 0.181 & & & & & & & & & & & \\
\hline G & 1.394 & 1.608 & 0.625 & 0.641 & 0.269 & 0.484 & & & & & & & & & & \\
\hline $\mathrm{H}$ & 1.442 & 1.442 & 0.451 & 0.648 & 0.279 & 0.315 & 0.332 & & & & & & & & & \\
\hline I & 1.253 & 1.295 & 2.125 & 2.056 & 2.848 & 2.668 & 2.892 & 2.819 & & & & & & & & \\
\hline $\mathrm{J}$ & 0.870 & 1.233 & 1.671 & 1.561 & 2.060 & 1.814 & 2.698 & 2.607 & 1.132 & & & & & & & \\
\hline $\mathrm{K}$ & 0.436 & 0.739 & 0.679 & 0.969 & 0.870 & 1.069 & 0.935 & 0.930 & 1.446 & 1.433 & & & & & & \\
\hline $\mathrm{L}$ & 0.758 & 1.113 & 1.948 & 1.768 & 2.650 & 1.869 & 2.739 & 2.589 & 0.518 & 0.593 & 1.052 & & & & & \\
\hline M & 1.319 & 1.311 & 1.676 & 1.777 & 1.617 & 1.323 & 2.445 & 1.450 & 0.802 & 1.260 & 1.226 & 0.391 & & & & \\
\hline $\mathrm{N}$ & 0.969 & 1.052 & 1.855 & 1.657 & 1.635 & 1.839 & 1.555 & 1.552 & 0.561 & 1.599 & 0.869 & 0.969 & 0.870 & & & \\
\hline 0 & 0.953 & 1.132 & 0.746 & 0.467 & 0.593 & 0.581 & 0.855 & 0.870 & 2.570 & 2.478 & 0.802 & 1.676 & 1.323 & 1.152 & & \\
\hline $\mathrm{P}$ & 0.786 & 0.710 & 1.233 & 1.354 & 1.103 & 0.979 & 1.384 & 0.938 & 1.442 & 1.818 & 0.931 & 1.069 & 0.933 & 1.094 & 0.992 & \\
\hline Q & 1.319 & 1.617 & 1.869 & 2.481 & 2.716 & 2.607 & 2.847 & 2.797 & 0.715 & 0.593 & 1.401 & 0.802 & 1.953 & 2.187 & 2.540 & 2.521 \\
\hline
\end{tabular}

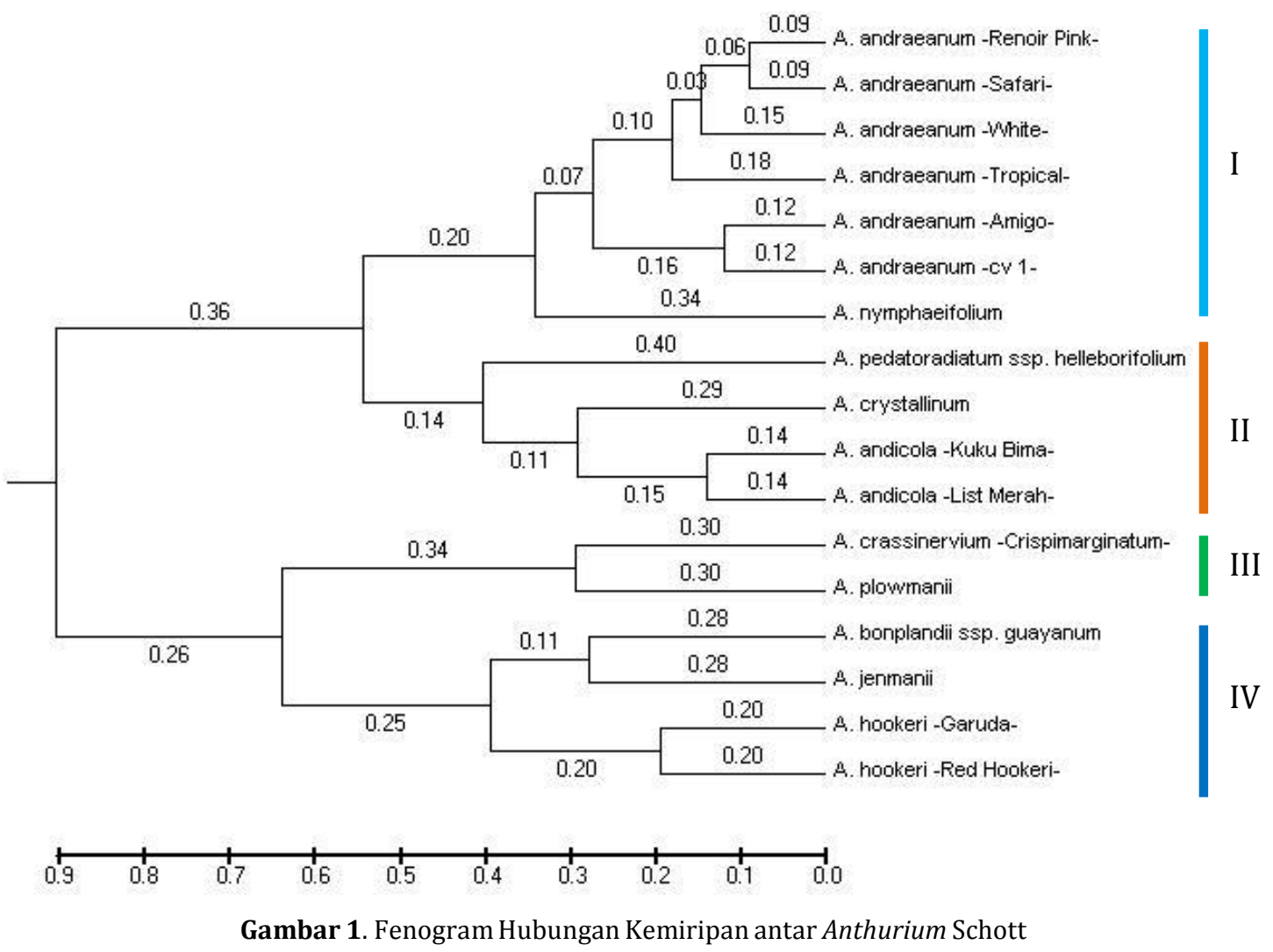

Kelompok I merupakan kelompok besar dengan persamaan sifat morfologi berupa helaian daun berbentuk bangun jantung dan warna bunga majemuk yang mencolok. Sedangkan Kelompok II mempunyai persamaan berupa ukuran helaian daun dengan panjang 35-48 cm dan lebar 25-30 cm, seludang bunga berbentuk lanset, dan warna tongkol yang kurang mencolok. Kelompok I dan Kelompok II ini merupakan Anthurium dengan pangkal helaian daun yang bertoreh. 


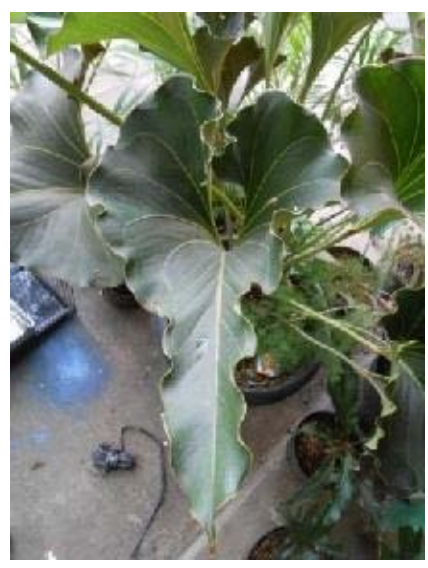

A

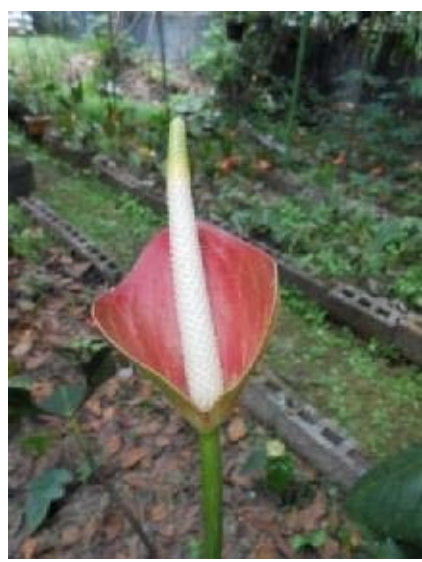

D

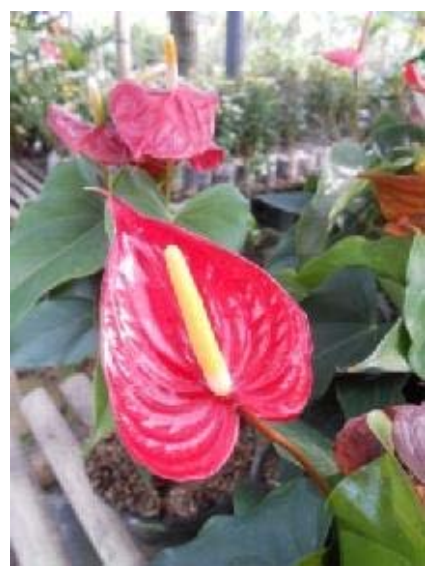

G

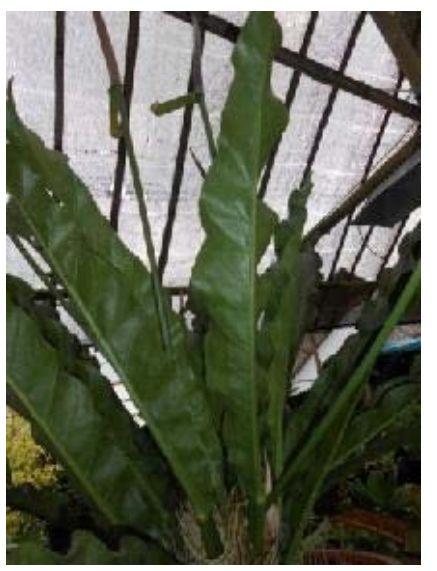

J

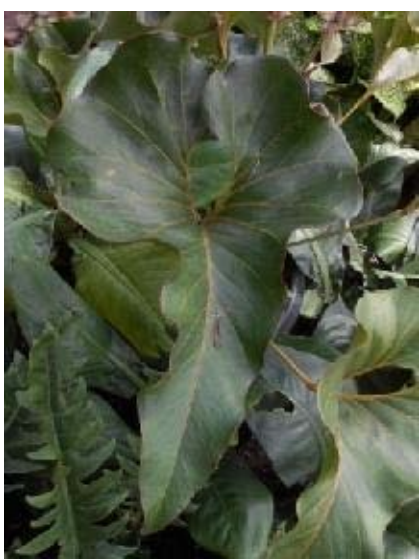

B

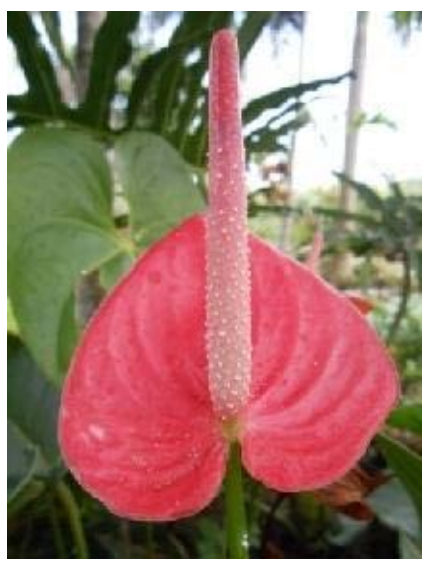

E

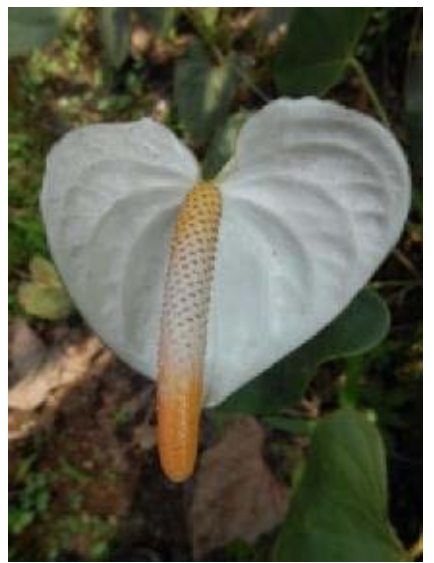

H



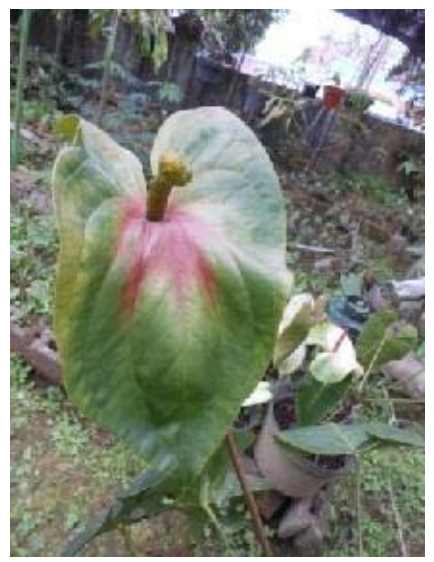

C
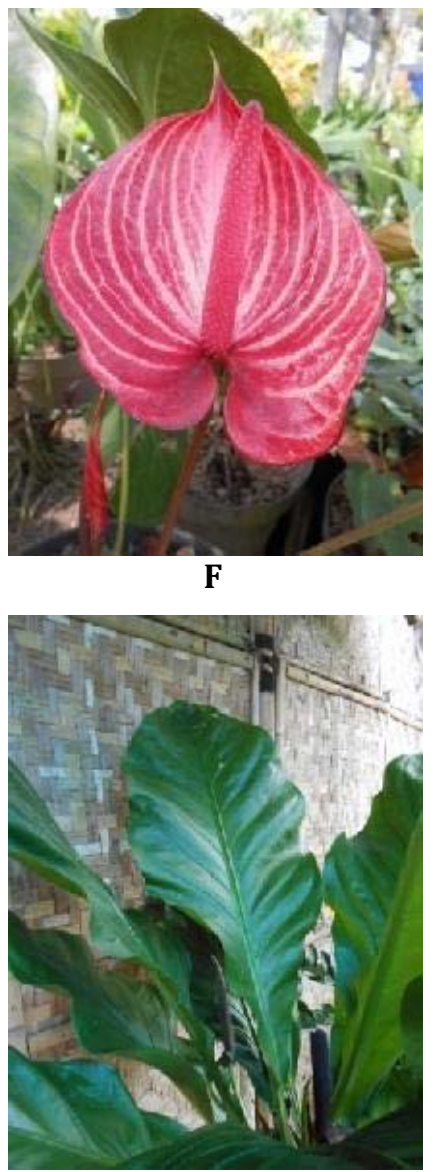

I

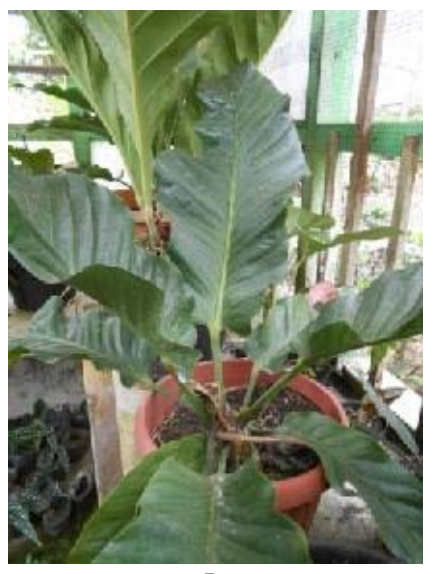

L 


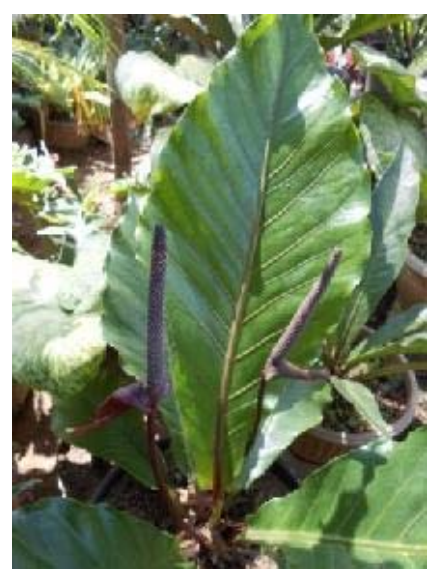

$\mathbf{M}$

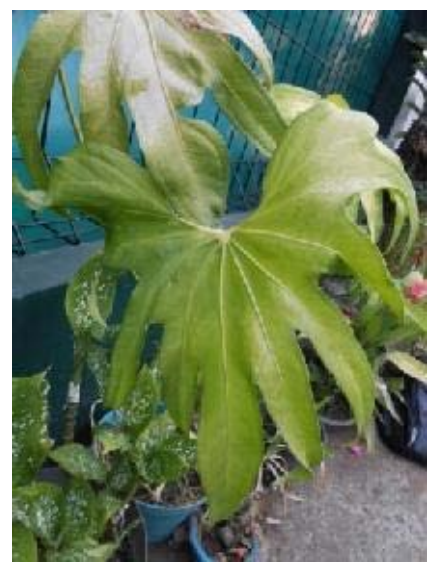

$\mathbf{P}$

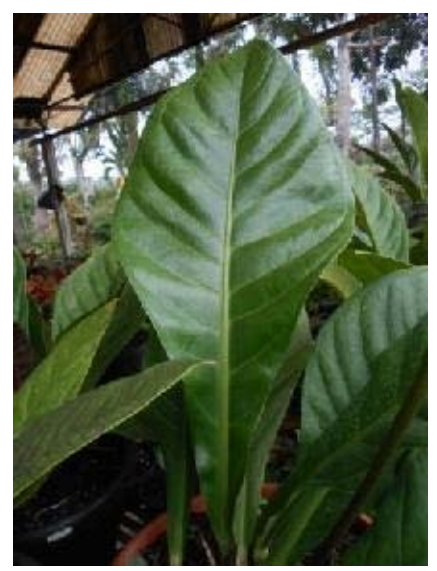

$\mathbf{N}$

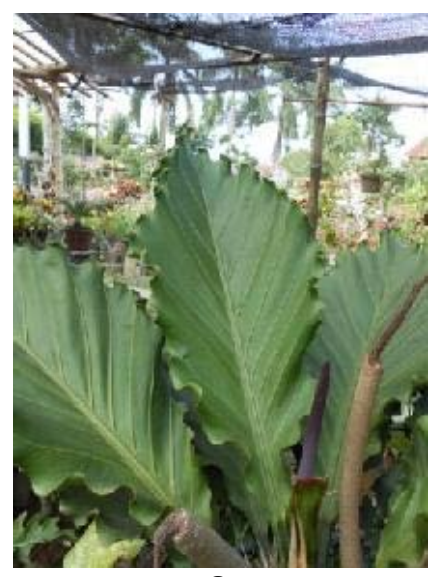

$\mathbf{Q}$

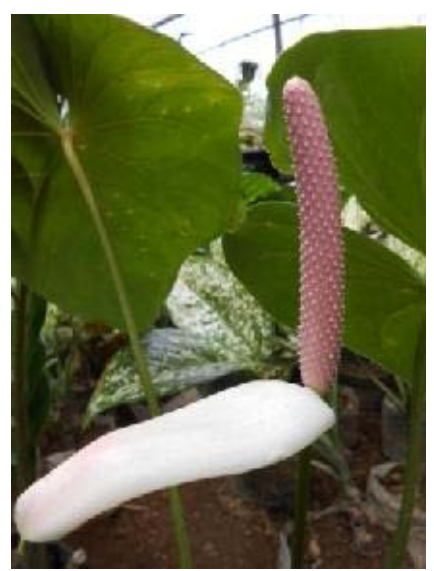

$\mathbf{0}$

Gambar 2. Foto penampilan Anthurium Schott yang diteliti

Keterangan : [ A ] A. andicola "Kuku Bima”, [ B ] A. andicola "List Merah”, [ C ] A. andraeanum “Amigo", [ D ] A. andraeanum "cv .1”,

[ E ] A. andraeanum "Renoir Pink", [ F ]A. andraeanum "Safari”, [ G ] A. andraeanum "Tropical”, [ H ] A. andraeanum "White",

[ I ] A. bonplandii ssp. guayanum, [ J ] A. crassinervium "Crispimarginatum”, [ K ] A. Crystallinum, [ L ] A. hookeri "Garuda”, [ M ] A. hookeri "Red

Hookeri”, [ N ] A. Jenmanii, [ O ] A. Nymphaeifolium, [ P ] A. pedatoradiatum ssp. helleborifolium, [ Q ] A. plowmanii

Kelompok III merupakan kelompok dengan persamaan sifat morfologi yaitu tinggi tanaman $>125$ $\mathrm{cm}$ dan bentuk helaian daun yang berbentuk bangun belah ketupat atau lanset. Sedangkan Kelompok IV mempunyai persamaan yaitu helaian daun berbentuk jorong atau menyudip, tangkai bunga berwarna agak keunguan, dan posisi seludang bunga berada di bawah helaian daun. Kelompok III dan IV ini merupakan Anthurium dengan pangkal helaian daun yang tidak bertoreh. Menurut Croat dan Sheffer (1983), A. andraeanum dan A. nymphaeifolium (Kelompok I) termasuk ke dalam satu seksi, yaitu Calomystrium sehingga mempunyai karakter morfologi yang mirip. A. pedatoradiatum ssp. helleborifolim termasuk ke dalam seksi Schizoplacium, A. crystallinum termasuk ke dalam seksi Cardiolonchium, sedangkan $A$. andicola termasuk ke dalam seksi Belolonchium (Kelompok II). Menurut Carlsen (2011), dari hasil penelitian tentang analisis filogenetik menunjukkan bahwa A. andicola lebih dekat kekerabatannya terhadap $A$. pedatoradiatum daripada terhadap $A$. crystallinum. A. plowmanii, A. jenmanii, $A$. crassinervium, A. bonplandii, dan A. hookeri (Kelompok III dan IV) termasuk ke dalam satu seksi yaitu Pachyneurium (Engler, 1905). Namun Croat (1991), mempunyai pendapat yang berbeda yaitu bahwa $A$. hookeri bukan termasuk ke dalam seksi Pachyneurium. Hal ini dikarenakan ada beberapa karakter $A$. hookeri yang bukan termasuk karakter seksi Pachyneurium. $A$. hookeri mempunyai buah yang berwarna putih, sedangkan seksi Pachyneurium mempunyai buah yang berwarna merah.

\section{KE S I M P U L A N}

Berdasarkan hasil dan pembahasan maka dapat diambil kesimpulan bahwa hubungan kemiripan ke17 taksa Anthurium yang didapatkan mempunyai koefisien dissimilaritas antara 0,181-2,892. Ketujuh belas taksa tersebut dapat dikelompokkan menjadi 4 kelompok. Kelompok I merupakan sister group dari Kelompok II, dan Kelompok III merupakan sister group dari Kelompok IV. Hubungan kemiripan terdekat yaitu antara A. andraeanum "Renoir Pink" dengan A. andraeanum "Safari", sedangkan hubungan kemiripan terjauh yaitu antara $A$. bonplandii ssp. guayanum dengan A. andraeanum "Tropical”.

\section{DAFT AR REFERENSI}

Anthurium [Internet]. 2012. Anonymous: [diakses pada tanggal 9 Maret 2012]. Tersedia di: http:// id. wikipedia. org/ wiki/ 
Anthurium.

Bailey LH. 1963. The Standard Cyclopedia of Horticulture. New York, USA: McMillan Co.

Bailey LH, Bailey EZ. 1976. Hortus Third: A Concise Dictionary of Plants Cultivated in the United States and Canada. New York, USA: MacMillan Co.

Breedlove DE. 1986. Flora de Chiapas. Listados Floríst, México 4: 1246.

Brown D. 2000. Aroids; Plants of the Arum Family. 2nd ed. Portland, USA: Timber Press.

Budhiprawira S, Saraswati D. 2006. Anthurium. Jakarta: Penebar Swadaya.

Bunting GS. 1979. Sinopsis de Las Araceae de Venezuela. Revista Fac. Agron. (Maracay). 10:139-290.

Carlsen, MM. 2011. Understanding the Origin and Rapid Diversification of the Genus Anthurium Schott (Araceae), Integrating Molecular Phylogenetics, Morphology and Fossils [dissertation]. University of Missouri-St. Louis, USA.

Chouteau M, Barabe D, Gibernau M. 2006. A Comparative Study of Inflorescence Characters and Pollen-ovule Ratios Among the Genera Philodendron and Anthurium (Araceae). International Journal of Plant Sciences. 167: 817-829.

Clifford HT, Stephenson W. 1975. An Introduction to Numerical Classification. London, England: Academic Press.

Croat TB, Sheffer RD. 1983. The Sectional Groupings of Anthurium (Araceae). Aroideana, 6: 85-123.

Croat TB, Sheffer RD. 1991. A Revision of Anthurium Section Pachyneurium (Araceae). Ann. Missouri Bot. Gard. 78: 539-855.

Davis PH, Heywood VE. 1973. Principle of Angiosperm Taxonomy. New York, USA: Robert E. Krieger Publishing Co.

Engler HGA. 1905. Araceae-Pothoideae. Das Pflanzenreich IV. 23B, Heft 21. Leipzig, Germany: Verlag von Wilhelm Engelmann. 1$330 \mathrm{pp}$.

Hamidah M, Karim AGA, Debergh P. 1997. Somatic Embryogenesis and Plant Regeneration in Anthurium scherzerianum. Plant Cell, Tissue, and Organ Culture. 49: 23-27.
Kadir A, Paeru RH, editor. 2007. Galeri Anthurium Daun. Jakarta: Penebar Swadaya. hal 1-152.

Karamura DA. 1998. Numerical Taxonomy Studies of the East African Highland Bananas (Musa AAA-East Africa) in Uganda [dissertation]. University of Reading-England.

Lie DS, Andoko A. 2007. Kunci Sukses Memperbanyak Anthurium Daun. Jakarta : AgroMedia Pustaka.

Martasari C, Sugiyatno A, Yusuf HM, Rahayu DL. 2009. Pendekatan Fenetik Taksonomi Dalam Identifikasi Kekerabatan Spesies Anthurium. Jurnal Hortikultura. 19: 155163.

Mayo SJ. 1982. Anthurium acaule (Jacq.) Schott (Araceae) and West Indian "Bird's Nest" Anthuriums. Kew Bull. 36: 691-719.

Ratnasari J, Krisantini. 2007. Galeri Tanaman Hias Bunga. Jakarta: Penebar Swadaya.

Rogers DJ. 1963. Taximetrics-New Name, Old Concept. Brittonia. 15: 285-290.

Rukmana R. 1997. Anthurium. Yogyakarta: Kanisius.

Shukla P, Misra SP. 1982. An Introduction to Taxonomy of Angiosperm. New Delhi, India: Vicas Publishing House Ltd.

Sneath, PHA, Sokal RR. 1973. Numerical Taxonomy: The Principles and Practice of Numerical Classification. San Fransisco, USA: W.H. Freeman.

Anthurium Si Bunga Ekor yang Memikat [Internet]. 2010. Suryanto, E: [diakses pada tanggal 23 Juni 2012]. Tersedia di: http:// wawaorchid. wordpress. com/ 2010/ 01/ 04/ anthurium-si-bunga-ekor-yang-memikat/.

Tamura K, Peterson D, Peterson N, Stecher G, Nei M, Kumar S. 2011. MEGA5: Molecular Evolutionary Genetic Analysis Using Maximum Likelihood, Evolutionary Distance, and Maximum Parsimony Methods. Molecular Biology and Evolution, 28:2731-2739.

Nama Tanaman itu A. jenmanii [Internet]. 2010. Zagoto, N:[diakses tanggal 12 Nopember 2012]. Tersedia di: http:// www. shnews. co/ detile-5517-nama-tanaman-itu-anthurium-jenmanii.html. 